\title{
Improvement of Methods in the Process of Criminal Law Teaching Based on Amendment of Criminal Law of the People's Republic of China
}

\author{
Wang Yiwei \\ Faculty of Law, Beijing Normal University, Beijing, China \\ wangyiwei931020@gmail.com
}

Keywords: Criminal law, Teaching method, Reason

\begin{abstract}
To overcome the defects in the teaching method and the problems in the application process, and to influence the teaching quality of Criminal Law, it is intended to introduce in detail the teaching philosophy, teaching content, teaching methods of criminal law and the influence of judicial examination on criminal law, and to analyze the causes of it more thoroughly, so as to benefit the teaching reform of criminal law. After research, it is concluded that the teaching method of Criminal Law can be improved from the aspects of improving the teaching level of teachers and learning from the post-modern curriculum concept. Of course, the problems in the teaching of criminal law are not formed in one day. It is impossible to solve the problems in one move. And it is urgent to take corresponding measures and countermeasures to improve the lag and dissatisfaction of the teaching of criminal law.
\end{abstract}

\section{Introduction}

Criminal law is a very important core course for law majors and plays a very important role in the legal education system (Ward, 2015). The importance of criminal law can be reflected in several aspects, as shown in Figure 1: first, the research object of criminal law is criminal law, and criminal law occupies an important position in the national legal system. Second, the teaching of criminal law occupies a very important position in the entire legal education (Gallini, 2014). In advanced legal education, whether it is undergraduate or general junior college students, criminal law is a major course, and in-class teaching requires more than 100 hours. Third, criminal law plays an important role in the national judicial examination. Most students of law majors wish to pursue a legal profession after graduation (Menis, 2014). However, they must pass the national judicial examination in order to engage in legal professions such as judges, prosecutors, and lawyers. In the judicial examination, criminal law has a large proportion (Cairns, 2014). Since criminal law is so important, as a law educator, it is obligatory to teach this course so that students can learn this course well (Bull, 2014). However, the current criminal law in China has certain problems in terms of teaching content and teaching methods, which seriously affects the dissemination of criminal law knowledge and the teaching effect of criminal law (Murphy, 2014). Therefore, in order to continuously improve the teaching effect of criminal law and make the importance of criminal law 
truly reflect, it is necessary to carry out reforms on the teaching content and teaching methods of criminal law.

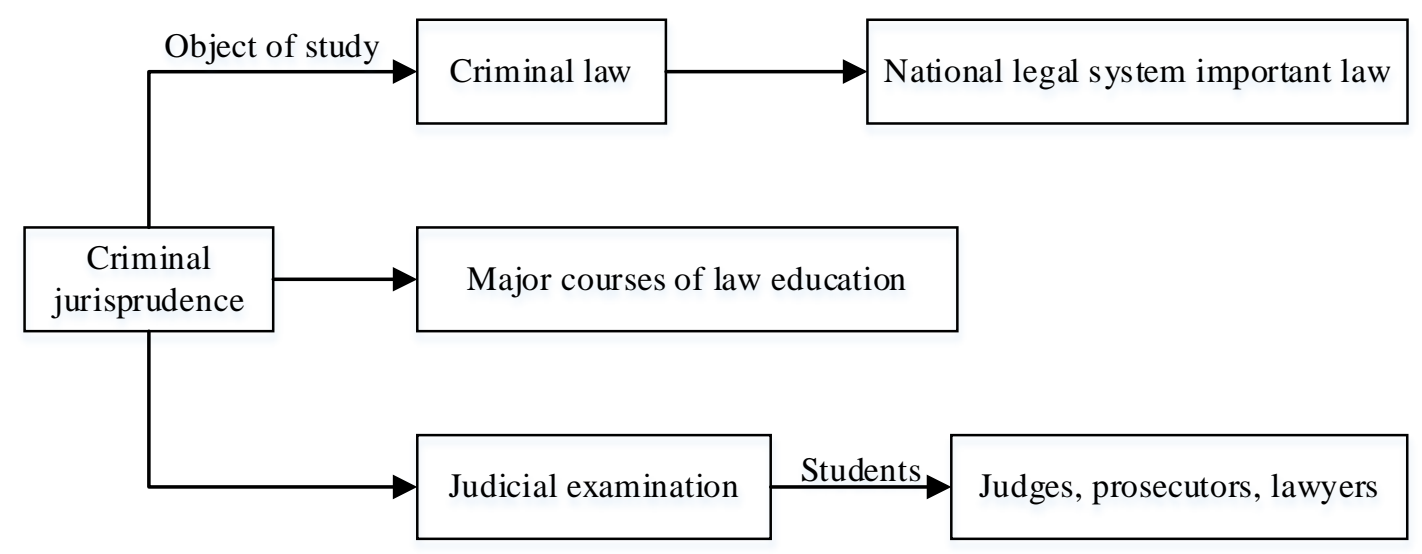

Figure 1. The importance of criminal law

\section{Theories}

Teaching is a unified combination of teacher's teaching and student's learning. Both are indispensable (Kirley, 2015). The teaching concept is a concentrated expression of people's understanding of the inherent rules of teaching and learning activities. It is also the people's perception of teaching activities and the basic attitudes and concepts they hold. It is the belief that people engage in teaching activities. The problem of the teaching philosophy of criminal law in China is mainly reflected in the teaching philosophy of teachers and the learning philosophy of students (Jr, 2014).

\subsection{Teacher's teaching philosophy}

Teachers only teach criminal law on the surface. In the teaching of criminal law in China, there are still some teachers who adhere to the "special" teaching philosophy and despise the intersection and communication between criminal law and other disciplines. When teachers teach criminal law knowledge, if it involves other subjects such as criminal procedure law and legal history, most of them will teach roughly on the grounds that other teachers will give special lectures. Criminal law is a humanities discipline. It is impossible to understand the basic principles and basic ideas without rich knowledge and good quality. In the teaching activities of criminal law, teachers should not only pay attention to imparting professional knowledge of criminal law, but also pay special attention to the humanistic qualities of students, as well as the cultivation of correct outlook on life and values and can't use "special" to represent "all" (Hurren, 2013).

Teaching for the completion of teaching tasks, that is, "task-based" teaching. In the current college teaching process, each faculty will set the teaching goals for each semester, and its original intention is good. However, in the market economy environment, the stimulation of material interests has had a tremendous impact on the original public welfare teaching activities. In the faculty of law of colleges and universities, some teachers are part-time lawyers who can't concentrate on teaching, or they concentrate on their own research projects without time to teach. Even if mandated by the college, the teachers are only doing the basic teaching tasks. In such a teaching environment, there is no channel for students to learn knowledge, and this is also the case for the teaching of criminal law (Roth, 2013).

Evaluate the student's learning outcome by the score of the written test. Teaching quality is the lifeline of teachers and the basis of survival of schools. Therefore, the evaluation mechanism of 
classroom teaching quality has become the first system to be constructed by various colleges and universities (D’Andrea, 2013). Nowadays, most colleges and universities evaluate the outcome of students' learning on the basis of the usual grade + final exam scores, which account for about $30 \%$ and $70 \%$. This leads students to memorize but not understand criminal law knowledge, lack of thinking, lack of communication with teachers, and lack of doubts about the criminal law knowledge with controversial points, thus affecting the cultivation of students' innovative ability (Buchtel, 2015).

\subsection{Students' learning philosophy}

Passive learning. The course of criminal law is generally offered in the first year of university or the second year of university. Due to the mechanistic learning mode of high school, most students have less initiative in learning, and the teaching method of "indoctrination" for teachers is not only Not to be excluded, but rather to cooperate. Since students have just experienced the mechanical learning mode of high school, they do not reject the teacher's "cramming method" teaching, but rather cooperate. The teacher has been passionately teaching on the rostrum, and the students are busy writing notes in the seat. The teacher-student interaction is less, and the students will not dare to propose the place where there is doubt. There is less interaction between teachers and students, and students will not take the initiative to ask questions.

Lack of the concept of modern criminal rule of law. Affected by the tradition of feudal autocracy in China for more than 2,000 years, some traditional criminal law thoughts such as "heavy punishment" and "penalty instrument theory" are rooted in the brains of ordinary people, and it also affect contemporary law majors to varying degrees. Student's awareness of criminal law. At the same time, it also affects the criminal law consciousness of contemporary students of law majors to different degrees.

\subsection{Analysis of the cause}

The reasons for the above problems are various, mainly reflected in the following points:

The teaching mode of criminal law is relatively backward. The traditional teaching mode in our country is based on teachers and focuses on the teaching of teachers. This model continues from primary education to higher education. In the classroom, the teacher is dominant, and the students are instilled with the idea of listening carefully and taking more notes, all subject to the teacher. The traditional criminal law teaching model that is still inherited at this stage is likely to lead students to lose their ability to innovate and practice. The process of studying criminal law is shown in Figure 2: 


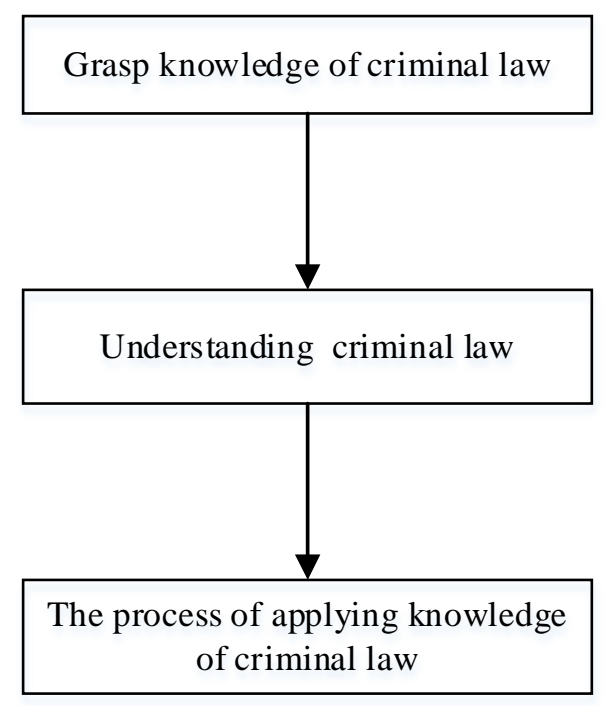

Figure 2. The process of learning criminal law

Insufficient teaching resources in the faculty of law of colleges and universities. In recent years, China's legal education has entered a period of rapid development. There are more than 600 colleges and universities offering law majors in China. However, due to the influence of the education system, the legal teaching resources of most colleges and universities still can't meet the teaching needs. First, the level of knowledge of teachers in criminal law needs to be improved. In addition to professional criminal law knowledge, the knowledge here should include political, history and philosophy related to criminal law knowledge. Second, there is insufficient teaching funding. China has continuously increased financial support for education, but the treatment of college teachers has not improved much, which is particularly evident in the central and western regions of China. The performance-based salary system of public institutions, including colleges and universities, which was implemented from January 1, 2010, has improved the enthusiasm of teachers for a certain degree, but its negative effects also exist, and the quality of teaching of corresponding courses has a risk of decline.

The negative influence of traditional Chinese legal thoughts. For thousands of years, the concept of "governing the country with severe law during the trouble times" has been regarded as the first principle for governing the country. Severe punishment is a traditional backward criminal concept. It embodies the severe punishment and is the most obvious in the history of ancient Chinese criminal law. Today, the concept of criminal rule of law in our country changes with the changes of the social environment, and it is constantly approaching the modern criminals. However, the impact of criminal law on the present day, including the impact on the teaching philosophy of criminal law, is still very big.

\section{Methodology}

\subsection{Teaching content of criminal law}

Reasonable teaching content is undoubtedly one of the key factors affecting the teaching quality of criminal law. However, the current situation reflects that the choice of the content of the criminal law course in China has not been able to adapt to the teaching task requirements of criminal law, and the corresponding problems need to be resolved. 


\subsubsection{The curriculum of criminal law is unreasonable}

The irrationality of the curriculum of criminal law in China is mainly reflected in two aspects: class time and textbook content.

There are few class hours to meet the requirements of high quality criminal law teaching. The current criminal law courses in China are divided into the pandect of criminal law and the dispersed theory in criminal law. The pandect of criminal law leads the dispersed theory in criminal law, while the dispersed theory in criminal law is the deepening and enrichment of the content of the pandect of criminal law. From the ten universities surveyed by the author, as shown in Table 1, except for Law School in East China University of Political Science and Law, Zhongnan University of Economic and Low, Sichuan University, and Guizhou Normal University, the total duration of the criminal law course is 108 hours. Among them, the the pandect of criminal law and the dispersed theory in criminal law each have 54 class hours. There are more than 400 crimes stipulated in China's criminal law. According to the requirements of the syllabus, all crimes should be explained. If the teacher wants to finish the theoretical knowledge of the 400 crimes in these 108 classes, the class time is obviously insufficient. At the same time, the setting of lectures and training sessions is not reasonable.

The setting of the textbook content is unreasonable. According to the catalogue of the core curriculum materials for law majors in colleges and universities across the country, at present, the criminal law textbooks used by the law schools of colleges and universities in China are generally the "Criminal Law" published by the Higher Education Press, except for a few colleges and universities using the criminal law textbooks prepared by the college. Its content is divided into general theory and branch theory of criminal law. The general theory of criminal law is divided into criminal law theory and punishment theory. The branch theory of criminal law specifically studies ten kinds of crimes, the crime constitution and the punishment of 400 specific crimes. It should be said that the content arrangement such as "Criminal Law" is undoubtedly helpful for in-depth understanding and mastery of the criminal law norms and the correct application of the criminal law norms. However, the above content arrangement of criminal law has a single problem of criminal law knowledge system. Such content setting can only provide students with a surface understanding of the criminal law norms and their scope of application, but students don't know the legislative reasons of criminal law nor the operability of criminal law norms in judicial practice.

Emphasize the teaching of theoretical knowledge and neglect the cultivation of practical ability

In the teaching of criminal law, some teachers generally pay attention to the explanation of the theoretical knowledge of books, and explain the problems contained in the knowledge roughly. They only require students to master according to the "General Theory" in the textbook. In the teacher's teaching philosophy, as long as the legal concept, logical system and theoretical framework are instilled into the students, the students can apply the legal concepts and legal principles to the specific case analysis. Therefore, teaching tends to focus on the explanation from "concept" to "principle", and timely introduces, analyzes and evaluates certain legislative or academic viewpoints in combination with ancient and modern concepts at home and abroad, but there are few new situations, new problems, and practical experiences in our judicial practice.

In the course of practical courses, it mainly includes mock courts, attending court trials, and professional internships. However, due to the influence of many factors, the practice of criminal law practice teaching in China has not achieved the desired effect. The students cultivated are only theoretical "scholars", which is contrary to the practical and applied characteristics of the discipline of criminal law, and it can't meet the requirements of training objectives. 
Table 1. The basic situation of criminal law courses in law major in ten universities

\begin{tabular}{|c|c|c|c|c|c|c|}
\hline \multirow{2}{*}{ College } & \multicolumn{2}{|c|}{$\begin{array}{l}\text { Criminal } \\
\text { jurisprudence(pandect) }\end{array}$} & \multirow[t]{2}{*}{ Remarks } & \multicolumn{2}{|c|}{$\begin{array}{l}\text { Criminal jurisprudence(sub- } \\
\text { pandect) }\end{array}$} & \multirow[t]{2}{*}{ Remarks } \\
\hline & Credits & Period & & Credits & Period & \\
\hline $\begin{array}{l}\text { East China } \\
\text { university of } \\
\text { political } \\
\text { science and } \\
\text { law Law } \\
\text { school }\end{array}$ & 4 & 72 & \multirow{6}{*}{$\begin{array}{l}\text { Teaching } \\
\text { takes up } \\
68 \text { class } \\
\text { hours. } \\
\text { Training } \\
\text { takes } 4 \\
\text { class } \\
\text { hours }\end{array}$} & 4 & 72 & \multirow{6}{*}{$\begin{array}{l}\text { Teaching } \\
\text { takes up } \\
68 \text { class } \\
\text { hours. } \\
\text { Training } \\
\text { takes } 4 \\
\text { class } \\
\text { hours }\end{array}$} \\
\hline $\begin{array}{l}\text { Xiamen } \\
\text { university } \\
\text { Law school }\end{array}$ & 3 & 54 & & 3 & 54 & \\
\hline $\begin{array}{l}\text { Sun Yat-sen } \\
\text { University } \\
\text { Law school }\end{array}$ & 3 & 54 & & 3 & 54 & \\
\hline $\begin{array}{l}\text { Zhejiang } \\
\text { University } \\
\text { Law school }\end{array}$ & 3 & 54 & & 3 & 54 & \\
\hline $\begin{array}{l}\text { Zhongnan } \\
\text { University of } \\
\text { Economics } \\
\text { and Law Law } \\
\text { school }\end{array}$ & 4 & 68 & & 4 & 51 & \\
\hline $\begin{array}{l}\text { Wuhan } \\
\text { University } \\
\text { Law school }\end{array}$ & 3 & 54 & & 3 & 54 & \\
\hline $\begin{array}{l}\text { Hunan } \\
\text { University } \\
\text { Law school }\end{array}$ & 3 & 54 & \multirow{3}{*}{$\begin{array}{l}\text { Teaching } \\
\text { takes up } \\
45 \text { class } \\
\text { hours. } \\
\text { Training } \\
\text { takes } 9 \\
\text { class } \\
\text { hours }\end{array}$} & 3 & 54 & \multirow{3}{*}{$\begin{array}{l}\text { Teaching } \\
\text { takes up } \\
45 \text { class } \\
\text { hours. } \\
\text { Training } \\
\text { takes } 9 \\
\text { class } \\
\text { hours }\end{array}$} \\
\hline $\begin{array}{l}\text { Yunnan } \\
\text { University } \\
\text { Law school } \\
\end{array}$ & 3 & 54 & & 3 & 54 & \\
\hline $\begin{array}{l}\text { Sichuan } \\
\text { University } \\
\text { Law school }\end{array}$ & 4 & 64 & & 3 & 48 & \\
\hline $\begin{array}{l}\text { Guizhou } \\
\text { Normal } \\
\text { University } \\
\text { Law school }\end{array}$ & 6 & 108 & $\begin{array}{l}\text { Teaching } \\
\text { takes up } \\
90 \text { class } \\
\text { hours. } \\
\text { Training } \\
\text { takes } 18 \\
\text { class } \\
\text { hours }\end{array}$ & 6 & 108 & $\begin{array}{l}\text { Teaching } \\
\text { takes up } \\
90 \text { class } \\
\text { hours. } \\
\text { Training } \\
\text { takes } 18 \\
\text { class } \\
\text { hours }\end{array}$ \\
\hline
\end{tabular}




\subsubsection{Analysis of the cause}

In the face of problems in the content of criminal law teaching, the root causes of problems must be found to solve problems better. Based on an in-depth analysis of the above problems, the main reasons are as follows:

The traditional factors of jurisprudence. In the 1950s, influenced by the former Soviet Union, China's legal education followed the Soviet model. During the "Cultural Revolution" period, China's education was in a state of turmoil. The public security law organs were great only in name but not in reality, and their legal education was almost non-existent. At the end of the "Cultural Revolution", the earliest batch of textbooks was published by the editorial department of the law textbook established by the Ministry of Justice. Later, several batches of national textbooks were published. This social and historical background determines that the content of the criminal law textbook in China inherits the tradition of the civil law system. It is precisely because of the influence of teaching materials and the requirements of the syllabus that the teaching of criminal law in China often only pays attention to the interpretation of the criminal law, pays attention to the interpretation of the keywords of the law, and ignores the lectures of general criminal law.

The main reasons for the problems in the theoretical and practical curriculum of criminal law in China are reflected in the following points: first, the "cramming method" teaching has ruled the criminal law classroom teaching in China. It only emphasizes the teaching of theoretical knowledge of criminal law, and the ability of students to solve criminal practice problems is not improved. Second, the original theoretical course of criminal law is less, and there is not much time for practical teaching. Third, because most of criminal law courses in China are offered in the first year of university, at this time, students have not yet understood the criminal procedure law and lack the criminal procedure basis for practical teaching. Fourth, the internships of law students are generally arranged in the senior year. During this period, students are under pressure to graduate to find a job, and it is difficult to ask them to concentrate on their internship. At the same time, the length of internship in law majors is not long, generally 2 to 3 months, and the cultivation of judicial practice ability is a process of continuous accumulation. It is unrealistic to cultivate strong judicial practice ability in these 2 to 3 months.

\subsection{Teaching methods of criminal law}

Education is an activity that imparts knowledge and enhances students' abilities. This kind of activity has certain regularity. Teaching method determines the quality of education, and if the teaching method is right, it will get twice the result with half the effort. Based on such a target requirement inspection, the traditional methods of criminal law teaching in China have many drawbacks.

\subsubsection{Teaching method is single and lacks pertinence}

In China's current law teaching, some teachers still follow the traditional "cramming method" teaching. In classroom teaching, teachers are always in an absolute dominant position. From the beginning to the end of a class, teachers are teaching the theoretical knowledge of jurisprudence. The students are basically passively accepting, lack of interaction between teachers and students, lack of appeal in the classroom, and the student's thinking is not following the teacher. This is a typical "teaching-listening-noting" teaching mode.

\subsubsection{Teaching methods are single}

With the popularity of computer and network technology, modern teaching has also presented 
new challenges for teachers. The use of network technology to assist law teaching can create and optimize the classroom structure, creating a better learning environment for students. In the current teaching of criminal law, some teachers still stay in the teaching methods based on blackboardwriting and dictation. They have not received training on relevant network teaching techniques, and they have not applied enough modern online teaching methods. This phenomenon is particularly evident in the older teachers, leading to excessive reliance on teachers' teaching, and the enthusiasm of students' self-learning is not fully mobilized, which greatly reduces the teacher's guiding function.

\subsubsection{Aging of teaching evaluation mode}

The development of higher education in China to this day has gradually proved that high scores in the school don't represent high ability. There are many reasons for this phenomenon, and the problems in the evaluation methods are one of the factors. In the current teaching mode, the closedbook exam is often used. The questions are mostly choices, short-answers and discourses. Students can basically get good grades by memorizing books, and students' ability to analyze and solve problems can't be assessed through such an examination. In China's criminal law teaching, although reforms have been carried out, most teachers pay attention to the results of written test to test students' mastery of the basic theory of criminal law, while ignoring the cultivation and investigation of students' basic skills and operating ability.

\subsubsection{Analysis of the cause}

The fundamental source of the problems revealed by the teaching methods of criminal law in China lies in the lag of legal education in China. To promote the reform of the teaching method of criminal law in China, it is necessary to find out the specific reasons for the problem, mainly reflected in the following aspects:

Historical human factors. The legal education in the true sense of our country begins after the "Cultural Revolution." After the end of the "Cultural Revolution", the goal of the training of law education at that time was to "cultivate political and legal cadres who are familiar with policies and decrees." Law education is based on the teaching of legal provisions, basically annotating the laws that have been formulated. The teaching methods that are appropriate to this are the "cramming" teaching methods popular in the university forum. This is the case in the whole legal education and law teaching. The teaching of criminal law is not likely to be an exception. As a result, some teachers' teaching methods are still the teaching mode of "teaching-listening-noting", and it has continued to this day.

Legal education resource factors. The influence and restriction of educational resources on the teaching methods of law is the most direct. Among the legal education resources, the most influential factors are teachers, teaching facilities and teaching funds. In terms of teachers, teachers' teaching philosophy, professionalism and practical ability directly affect the application of criminal law teaching methods and the achievement of teaching effects. In addition, teaching facilities and funding also affect the choice of teaching methods and the improvement of teaching result. If there is a lack of educational resources, people can only choose teaching methods with lower education costs. Rich educational resources can make people choose teaching methods with higher education costs. Network distance teaching is the most obvious example.

\section{3 "Criminal Law" teaching method innovation target}

The innovative goal of the teaching method of "Criminal Law" is to establish the direction of innovative application of teaching methods. First of all, the innovation goal of the teaching method of "Criminal Law" should be consistent with the training objectives. At present, the legal 
profession usually has three views on the training objectives of law education: one is the elite; the second is the vocational education; the third is the general knowledge. The goal of education and training should be to train practitioners with basic qualities and abilities of the legal profession. Through the educational process, they are required to master the basic knowledge and basic theories of the major legal departments. The innovation goal of the teaching method of "Criminal Law" should be closely related to the realization of the training objectives of our country; secondly, the innovation goal of the teaching method of the "Criminal Law" of the undergraduate course of law should be in line with the actual judicial examination of the country. The National Judicial Examination is a vocational qualification examination that focuses on the examination of current legal provisions and judicial practice issues. Education needs to be tested by judicial examinations, focusing on the education and training of students' professional ability. In summary, the innovative goal of the teaching method of "Criminal Law" of the undergraduate course of law is to cultivate students' critical criminal thinking ability, ability to analyze and solve problems and innovation ability, and to serve criminal legislation and criminal justice practice in China.

\subsection{Innovative approaches to the teaching methods of "Criminal Law"}

The innovative approach to the teaching method of "Criminal Law" is a new measure to realize the innovative application of teaching methods. The effective ways of the new "Criminal Law" teaching methods can be explored from the following two aspects, as shown in Figure 3:

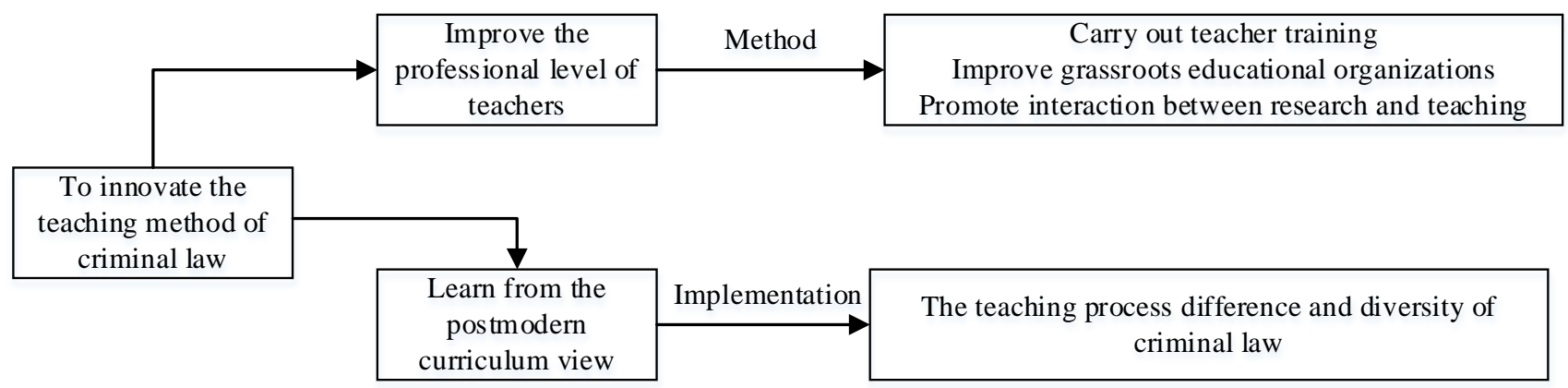

Figure 3. Innovative approaches to teaching methods of criminal law

Focus on improving the professional level and teaching ability of teachers in criminal law

The teaching ability of teachers is a key factor in determining the quality of teaching. Carry out teacher training and teaching consultation in a planned manner, train a double-teacher faculty, and improve the professional level and teaching ability of young and middle-aged teachers; improve grassroots teaching organizations such as the teaching and research room of the criminal law, teaching teams, and curriculum groups; adhere to the collective preparation of lessons, and deepen the study of key issues in the teaching of "Criminal Law"; improve the mentoring mechanism of the old and middle-aged teachers; explore ways to scientifically evaluate teachers' teaching ability; promote the interaction between scientific research and teaching, and timely transform scientific research results into teaching content.

Using the post-modern curriculum concept to realize the difference and diversity of the teaching process of "Criminal Law"

The role of postmodernism in education is mainly reflected in the changes of the principles of openness, difference, and pluralism advocated by postmodernism introduced into the design principles of teaching curriculum by researchers of educational philosophy. Among them, the most influential doctrine is the post-modern curriculum concept of American scholar William E. Dole. 
The post-modern curriculum concept advocates the concept of diversity and pluralistic education, builds a tolerant and active classroom atmosphere, and tries to make the whole classroom teaching lively, so that students can fully show themselves, display the subjective consciousness and unique personality, so that they gradually have the values of freedom of thought, compatibility and independence. In the teaching process of the "Criminal Law" of the undergraduate course of law, it can provide a theoretical basis for the post-modern curriculum concept and open up a new way of innovation in the teaching method of "Criminal Law".

\section{Experiments}

The innovative value of teaching methods lies in the search for effective teaching methods. At present, the academic circles have carried out many useful explorations on the innovative application of the teaching methods of "Criminal Law". Among them, the "comprehensive teaching method" and the "three-dimensional" teaching method are more typical. The existing exploration is still preliminary, and new explorations and attempts are urgently needed. The new attempt of the innovative application of the teaching method of "Criminal Law" focuses on the comprehensive application of the innovative "Criminal Law" teaching method.

Each teaching method has a certain historical background and institutional needs; it is also not the only and exclusive teaching method. Every teaching method of "Criminal Law" should be used correctly to make it fully functioning; teaching is an art. The teaching method of "Criminal Law" needs constant innovation and improvement, so that it can be continuously developed and optimized. Therefore, in the practice of teaching innovation in "Criminal Law", teachers must truly apply flexible methods, sum up experience in a timely manner, and innovate the comprehensive application of the teaching methods of "Criminal Law". In the process of teaching, it focuses on the innovative application of the comprehensive application of the teaching method of "Criminal Law", and strives to realize both the theoretical system teaching and the case analysis; it not only pay attention to the theory teaching in the class, but also take into account the expansion of extracurricular practice; it not only pay attention to summing up experience, improving teaching level, but also pay attention to students as the center and pay attention to cultivating students' innovative ability. For example, when conducting case teaching, it focuses on selecting typical cases (such as poisoning case of postgraduate students in Fudan University, Gu chunfang's fund raising fraud case, Bo Xilai case, etc.) for demonstration. In the process of asking questions, analyzing problems and solving problems, it focuses on summarizing theories from the cases, and then using the theory to solve the practical problems involved in the cases, and deepening the theoretical teaching while cultivating students' ability to analyze and solve problems. In the experiential teaching, it consciously raises the level of practical teaching and strives to overcome many objective shortcomings of practical teaching, and it takes students as the center to strengthen the cultivation of students' critical criminal thinking ability and innovative ability.

\section{Conclusions}

The problems in the teaching of criminal law are not formed in one day. It is impossible to solve the problems in one move. It is urgent to take corresponding measures and countermeasures to reverse the lag and dissatisfaction of criminal law teaching. On the basis of analyzing the problems in the teaching of criminal law in our country and the reasons for their formation, how to find a reasonable way to cultivate talents in the teaching of criminal law is an inevitable and urgent problem. 


\section{References}

[1] Ward, R. M. (2015). The criminal corpse, anatomists and the criminal law: parliamentary attempts to extend the dissection of offenders in late eighteenth-century england. Journal of British Studies, 54(1), 63.

[2] Gallini, B. (2014). Teaching federal criminal law: survey says. 'it's hard'. Social Science Electronic Publishing, 82(3), 198202.

[3] Gallini, B. (2014). From philly to fayetteville: reflections on teaching criminal law in the first year. four years later. Social Science Electronic Publishing, 172(6), 1683-1688.

[4] Menis, S. (2014). Non-traditional students and critical pedagogy: transformative practice and the teaching of criminal law. Teaching in Higher Education, 22(2), 1-14.

[5] Cairns, J. W. (2014). Teaching criminal law in early eighteenth-century scotland: collegia and compendia. Fundamina A Journal of Legal History Part Essays in Honour of Laurens Winkel Special Issue, 20(1), 90-99.

[6] Bull, G. (2014). The opinion of the catholic church for the first three centuries, on the necessity of believing that our lord jesus christ is truly god (1825) [hardcover]. Social Science Electronic Publishing, 82(3), 198-202.

[7] Murphy, J. G. (2014). “in the penal colony” and why i am now reluctant to teach criminal law. Criminal Justice Ethics, 33(2), 72-82.

[8] Kirley, E. A. (2015). Are we ethically bound to use student engagement technologies for teaching law?. Law Teacher, 49(2), 219-241.

[9] Jr, R. A. F. (2014). Teaching the wire: integrating capstone policy content into the criminal law curriculum. Pakistan Journal of Biological Sciences Pjbs, 16(12), 593-7.

[10] Hurren, E. T. (2013). The art of medicine the dangerous dead: dissecting the criminal corpse. Lancet, 382(9889), $302-303$.

Roth, R. E., Ross, K. S., Finch, B. G., Luo, W., \& Maceachren, A. M. (2013). Spatiotemporal crime analysis in u.s. law enforcement agencies: current practices and unmet needs. Government Information Quarterly, 30(3), 226-240.

[11] D’Andrea, W., Lou, B., Fortunato, A., \& Spinazzola, J. (2013). Play to the whistle: a pilot investigation of a sports-based intervention for traumatized girls in residential treatment. Journal of Family Violence, 28(7), 739-749.

[12] Buchtel, E. E., Guan, Y., Peng, Q., Su, Y., Sang, B., \& Chen, S. X., et al. (2015). Immorality east and west: are immoral behaviors especially harmful, or especially uncivilized ? Personality \& Social Psychology Bulletin, 41(10), 1382. 